\title{
The Influence of Individual Characteristics, Organizational Characteristics and Work Environment on Employee Performance and Its Impact on the Performance of Bkkbn Representative Organization of Aceh Province
}

\author{
Ihya \\ Muhammad Adam \\ Ridwan Nurdin \\ Study Program of Master Management \\ Economics and Business Faculty \\ Syiah Kuala University
}

\begin{abstract}
The performance that is achieved is an organization basically is the achievement of the employees themselves. It is started from the employees at the higher until the lower level. The performance concept in a government emerges when a government institution starts trying to introduce a new concept in the management of public affairs becomes good governance. In a government, it can be said that it will be successful if you have a clear as well as measurable vision and mission. It means that vision and mission will never be meaningful when it is not actualized in performance in terms of creating good governance. The factors that influence the success rate of an organization are employee performance. Every organization always expects its employees to succeed, because having superior employees will ensure optimal contribution to the organization. Employee performance cannot be separated from individual characteristics, organizational characteristics and work environment. This study is to see the influence of individual characteristics, organizational characteristics, and work environment on organizational work outcomes which are mediated by employee performance. The object of research is all office employees from the Representative of the National Family Planning Population Board in Aceh Province. The results of this study indicate that some individual characteristics, organizational characteristics and work environment influence employee productivity. Likewise, employee productivity, individual characteristics and organizational characteristics partly influence organizational efficiency. In this study, employee performance mediates the influence of individual characteristics, organizational characteristics, and work environment partially on organizational performance.
\end{abstract}

Keywords: Individual Characteristics, Organizational Characteristics, Work Environment, Employee performance, Organizational Performance

\section{Introduction}

Human resources are required to provide competitive advantages in an effort to support organizational performance optimally. Competitive advantage can be seen in aspects of employee knowledge, skills, attitudes and behaviors which are aimed at achieving organizational goals. Nowadays, the rapid development of technology, information and science places the impact of globalization on a strategic position and has a significant impact on changes in systems and values in society, community organizations as well as government organizations, including the National Family Planning Population Board (BKKBN). In carrying out the duties from the government in the field of population control and the implementation of family planning, BKKBN organizes the functions, namely: the formulation of national policies in the field of population control and implementation of family planning, with several tasks, namely 1) establishing norms, standards, procedures and criteria in the control of population and family planning, 2) advocacy and coordination in the field of population monitoring and family planning, 3) communication, information and education organizations in the field of population monitoring and family planning, 4) national population control estimates, 5) preparation of the KKBPK program design, 6) consultant management of family planning / family planning specialists, 7) management and introduction of contraception and drugs for the needs of national fertile couples, 8) management and control of family information systems, 9) increasing the capacity and participation of community organizations at the national level in monitoring services and promoting family planning and reproductive health, 10) designing the development of family development programs through increasing family sustainability and welfare; 11) expanding opportunities and increasing the role of public organizations at the national level in the field of family life through sustainability and family welfare, 12) standardization of family planning services and certification for family planning counsellors/family planning officers, 13) monitoring and evaluation of population control and family planning, 14 ) guidance, assistance and aid in the field of population control and family planning. 
Strategic issues that occur and show the performance of BKKBN is still low, namely 1). The trend of total birth rates (TFR/Total Fertility Rate) according to the Indonesian Health Demographic Survey (SDKI) in 2007 is to 3.1, it decreased in 2012 to 2.8 and the SDKI in 2017 dropped by only 1 point, namely at 2.7 . The TFR data is still far from the national expectation target, namely: 2.1. Whereas when it is compared with the achievement rate of TFR in the Provinces Level of Sumatra, the position of Aceh Province is in the lowest rank after North Sumatra and Riau. This shows contradictions with the support of infrastructure including large enough budget to reduce the total fertility rate (TFR) in Aceh Province (data source: Budget Implementation List (DIPA) / Budget Activity Plan of Ministry/Institution (RKAKL) BKKBN Representatives of Aceh Province in 2015-2017). 2). Contraceptive Prevalence Rate (CPR), according to the 2017 SDKI, shows an unattractive result, which is still at 52\%, this also puts Aceh Province as the lowest province of achievement in Sumatra. 3). For the infant mortality rate, Aceh Province has not succeeded in significantly reducing the mortality rate, in which at the 2010 Census it was 27.9 and only slightly decreased in 2015 which was 24.8 (Inter-Census Population Survey (SUPAS 2015). 4). Furthermore, the rate of breastfeeding (ASI) exclusively for infants, the achievement rate is still very low at 23\% (source from Health Office in 2017) if it is compared to the National achievement at 38\%. 5). The efforts to reduce the number of stunting (short-born babies, due to chronic malnutrition) Aceh Province is still in poor level because it is far below the national average, in which the National average is at $29.6 \%$, while Aceh is at $34.5 \%$. 6). And the maternal mortality rate in Aceh Province in 2017 in 148 cases/1,000 women who gave birth, it only decreased slightly when it is compared to 2016 which is 169 cases (sourced from nutrition and family health section of Health Office in Aceh).

There are 2 indicators in contract performance of BKKBN Representatives at Aceh Province in 2017 that have been established, namely strategic target performance contracts (points 1-3) and program target performance contracts (points 4 - 12). There are some that have been achieved well and they are stated (positive $/+$ ) and some that have not been achieved (negative/-), namely:

1. The decrease in the total fertility rate (TFR) per woman of childbearing age (WUS) 15-49 years old at 2.51 (2017 RPJMN Survey) from the target at 2.74. (+)

2. The decrease in the percentage of unmet need for family planning (Unmet Need) is still far from expectations, which is at $13.07 \%$ from the target at $9.88 \%$. (-)

3. The increase in the percentage of MKJP Active KB participants (Long Term Contraception Method) is at 9.35\% from the target at $8.62 \%$. (+)

4. The decrease in birth rates of adolescents (15-19 years old AFSR) is 21.9\%, but the data according to the 2016 RPJMN survey is still at $26.6 \%$. (-)

5. The decrease in the percentage of unwanted pregnancies from couples of childbearing age (15-49) years old is $6.9 \%$, and the achievements according to the 2017 RPJMN survey have exceeded at $2.7 \%$. (+)

6. The increase in the median of first marriage age is 20.6 years old, but the achievement rate according to the 2016 RPJMN survey is still at 20.0 years old. (-)

7. The increase in the percentage of family knowledge about population issues at $42.7 \%$ and the achievements according to the 2016 RPJMN survey have exceeded the target at $44.9 \%$. (+)

8. The increase in the percentage of PUS knowledge about contraceptive methods (all modern KB methods) is at $29.3 \%$, but the achievement is still far from expectations at $11.3 \%(-)$

9. The percentage target for achievement in budget implementing performance is at $>90 \%$, but the achievement is only at $67.74 \%$. (-)

10. The percentage target for achievement output is at $>95 \%$, but the achievement is still low at $87.24 \%$. (-)

11. The percentage target for budget absorption is at $>95 \%$, while the achievement is only $87.36 \%(-)$

12. The percentage target for inventory items that are recorded at SIMAK BMN is at $100 \%$, and the achievement is maximal at $100 \%$ as well.

According to the results of organizational evaluation performance from BKKBN Representatives of Aceh Province in November and December 2017 which was conducted in January 2018 and the number of achievement figures that are still below the target / expectation, BKKBN Representatives of Aceh Province still desperately need smart work by mobilizing all the ability of existing resources to achieve organizational goals, either human resources, technology, supporting facilities or conducive work environment that can support employee performance in achieving better organizational performance output. Employee performance is the overall level of a person success in a given period when he performs the tasks when it is compared to the results of standard work, goals or targets or criteria that are predetermined and agreed upon (Rivai, 2014). Similar to the view of Rivai, the opinion of Prabú (2013: 67) states that employee performance is the performance or quality of work, both quantitative and qualitative, achieved by combining human resources over a period of time when carrying out their work duties in accordance with their responsibilities. The problems which are related to the employee performance at the BKKBN Representative in Aceh Province are: 
1. There are still many employee performance contracts that have not been achieved as it is expected, namely, the target percentage for the achievement of budget implementing performance is at $>90 \%$, but the achievement is only at $67.74 \%$. (-).

2. The percentage target for achievement output is at $>95 \%$, but the achievement is still low at $87.24 \%$. (-),

3. The target percentage for budget absorption is at $>95 \%$, while the achievement is only at $87.36 \%$ (-), which means that not all of the listed activities in the employee performance target (SKP) can be carried out by each employee.

4. There are still many employees who are not adept at using technology tools in carrying out daily activities so that they are still asking for help from friends or their children in filling in sivika (e performance).

5. The level of transfer/mutation of employees is minimal so that each of them has low work experience and only masters a few of sub-programs, this condition is also expected to influence the saturation of employees.

Characteristic of an individual is a character that is owned by each person which varies from person to another. The problems of individual characteristics in the BKKBN Representatives of Aceh Province are as follows:

1.Human Resources (HR) management of KKBPK program at BKKBN Representatives of Aceh Province has divided their duties and responsibilities as well as has determined their organizational structure, but in terms of amount, it still feels less when it is compared to the workload and scope of work in 23 Districts / Cities, 298 sub-districts and 6,474 villages in Aceh Province with only 96 people as civil servants. And it is added with 27 people with the status as outsourced workers (contract workers), namely 9 people of the security office, 8 people of cleaning service staff, 6 people of the driver, and 4 people of pre-service personnel. The most dominant age group is the age group of above 40 years old, and some do not master computer/technology applications. The implication is that in terms of the division of tasks that there are less balanced between employees. It is clear that there are differences in productivity between employees, which in turn it has an impact on the attitudes and interests of employees in completing tasks that are less balanced.

2.The last dominant level of education is a Bachelor degree of 62 people (50.41\%), high school graduation of 34 people (27.64\%), Master degree of 18 people (14.64\%), Diploma degree of 7 people (5.69\%), and for elementary and junior high school graduation at each of 1 person $(0.81 \%)$ from the total number of employees. While the level of tiered education (leadership training) at level IV, III, and II has been participated by employees is still very low, it is only 29 people $(23.57 \%)$, and 67 people $(54.47 \%)$ have not participated in leadership training, while 27 people $(21.95 \%)$ of outsourcing workers did not get the opportunity to participate in the training, but they still have the opportunity in other technical training according to their respective fields. Referring to this tiered training data which is still relatively low, it is expected to influence employee performance, which in turn will have an impact on the achievement of organizational performance.

3.The department of training and development itself is still focused on increasing the capacity of the work and operational partners in the field, while the internal program managers (in this case the outsourcing staff and employees of BKKBN Representative in Aceh Province) have not become the main targets of capacity improvement which is carried out by the Training and Development Division of BKKBN Representatives in Aceh Province. It can be seen from the budget support for employee capacity improvement of BKKBN representatives in Aceh Province who are still minimal and not according to their needs. Organizational characteristics namely regularity which is manifested in the hierarchy of jobs, duties, authority, responsibilities and payroll systems. The problems of organizational characteristics that occur in BKKBN Representatives in Aceh Province are:

1.BKKBN Representatives of Aceh Province are non-ministerial institutions with vertical status and refer to the vision, mission, goals and national strategic objectives, with the institutional structures that are headed by an echelon II as a chief representative, 6 echelons III and 20 echelons IV, as well as functional positions.

2. There is not strong enough signal of internet network facilities in each working space and there are not telecommunications available either in all spaces. To send mail or fax must be done from another room by borrowing the related equipment.

3. Incorporated working space in one room for echelon 4, analysts, compilers, and some functional officials are necessary to get attention in the arrangement in order to increase working comfort among components.

4. Susunan pangkat/golongan pegawai dibagi menjadi 4 golongan, yaitu golongan I, golongan II, golongan III dan golongan IV, sedangkan untuk tenaga outsourcing digolongkan dalam kelompok tersendiri.

5. The rank/class of employees is divided into 4 groups, namely group I, group II, group III and group IV, while those for outsourcing are classified into separate groups.

6. If it is counted in terms of numbers, computer/laptop/ notebook facilities are more than the total number of employees of BKKBN Representative in Aceh Province. 
But the distribution is not good. It is still limited to certain fields. There are still many other fields that have not received sufficiently and adequately facilities to support employee performance, and there are more insufficient printers.

7. Operational coverage from the activities of BKKBN Representative at Aceh Province in 6,474 villages, 289 subdistricts and 23 Districts / Cities in Aceh Province with supporting facilities and infrastructure partly is in good condition but many of them are in poor conditions, such as the age of 2-wheeled and 4-wheeled vehicles which has been used for more than 10 years.

The work environment is all instrumental equipment and materials where a person works with work methods and working conditions both individually and as a group. The work environment problems that appear in BKKBN Representative at Aceh Province are:

1.There is a frequent power outage that results in the room temperature setting is less stable.

2. The employees feel uncomfortable to move due to the workspace is not spacious enough. But if it is seen from the building area, it is wide enough, it is $1,997 \mathrm{~m}^{2}$.

3. The employees feel uncomfortable and less secure due to the guests who often come at working hours.

4. The employees must be extra careful when they go up and down using the stairs due to its high steepness.

5. The intensity of active communication among employees personally is not very good, this is probably due to the uneven distribution of workload.

6. There is still less intensity of communication between sections in the form of preparatory meetings implementation for certain momentum activities so that by the time of the activity implementation there is not good coordination among them.

The failure to achieve program performance in one of the provinces also contributes to the overall program failure at National level. On the contrary, the positive performance achievement from the Provincial BKKBN representatives becomes the accumulated success of BKKBN performance achievement in National. The above situation still shows a large bias/gap between expected hope and reality. Intelligent and high-performance work is still urgently needed from the managers \& implementers of the Family Development Family Planning Population Program (KKBPK) to continue doing and looking for innovations according to the changes in the organizational strategic environment, both KKBPK program managers at the National level and their representatives throughout the Provinces in Indonesia, which is called the Provincial BKKBN Representative, and includes BKKBN Representatives of Aceh Province which become the locus in this study.

\section{Theoretical Study}

\subsection{Organizational Performance}

Organizational effectiveness is also shown in how the action process to achieve goals. Organizational indicators are rather complex and consist of several interrelated variables. One of them is the individual performance of each member in the organization. Sunyoto (2013) argues that organizational success is determined by the ability of human resources, and this ability manifests itself in the form of employee performance. Mahsun (2012: 77-78) mentions that the indicators which are used in implementing organizational performance measurements are as follows:

1. Input indicator (input)

2. Indicator (process)

3. Output or indicator (output)

4. Outcome indicator (outcome)

5. Benefit indicator (benefit)

6. Impact indicators (impact)

\subsection{Employee Performance}

In accordance with Government Decree No. 46 (2011), performance appraisal of civil servants (PNS) is a systematic process of assessment which is carried out by officials in evaluating the objectives and work behavior of civil servants. Work performance is the result of work which is carried out by civil servants in organizational units in accordance with the work objectives and work behavior of employees. Employee Goals (SKP) - these are work plans and objectives that must be achieved by government officials. Donelly, Gibson and Ivancevich (in Lijan Poltak Sinambela, 2012: 11), state that individual performance is influenced by six factors, namely: 1) expectations regarding rewards, 2) encouragement 3) abilities, needs and characteristics, 4) perceptions of tasks, 5 ) internal and external rewards.

6) perceptions from the level of reward and job satisfaction. Furthermore, there are 6 (six) performance indicators that are delivered by Robbin, (2006: 260), namely: 
1. Quality.

2. Quantity.

3. Timeliness.

4. Effectiveness.

5. Independence.

6. Work commitment.

\subsection{Individual Characteristics}

Individual characteristics are characteristics that each person has in the form of interests, attitudes, and needs that someone brings to their work environment (Siregar, 2014). Personality characteristics are the characteristics that show differences between someone who has motivation, initiative, ability to remain strong, to overcome tasks before their completion or to solve problems, or how to improve changes that are closely related to the environment, which have individual indicators. According to Ginting, (2010) in Sugijanto (2011), says that individual characteristic indicators include 4 (four) main indicators, namely:

1) Capabilities that are in accordance with the company expectations.

2) The value that is in accordance with the company expectations.

3) Attitudes that are in accordance with the company expectations.

4) Interests that are in accordance with the company expectations.

\subsection{Organizational Characteristics}

According to Wahab (2008: 4) an explanation of organizational characteristics, including 1) social units, 2) targeting (aiming), 3) having a deliberately structured action system and 4) with clear boundaries. The indicators are organizational structure and organizational culture. According to Dafta, (2007) states that an organization has two main dimensions, namely structural dimensions, which determine the characteristics of the organizational structure, and contextual dimensions, which include the characteristics of organizational size, organizational strategy, technology, organizational environment, and organizational culture. While Daft, (2007), says that the factors that influence organizational characteristics are: organizational structure, organizational size, organizational strategy, IT organization (information technology), organizational environment, organizational culture.

\subsection{Work Environment}

Sedarmayanti, (2012: 21), at Faridila Hashibuan, (2018), argues that work environment is all instrumentation equipment and materials in which a person works, work methods, and working conditions that are suitable for individuals and groups. Next is Sedarmayanti, (2012: 21) also states that in general the type of work environment is divided into two, namely the physical work environment and the non-physical work environment. The indicators of work environment, in accordance with Sedarmayanti (2011: 21), are related to the ability of employees: 1) lighting, 2) air temperature, 3) humidity, 4) air circulation, 5) noise, 6) mechanical vibration at work, 7) smell at work, 8) color, 9) decoration at work, 10) music at work, 11) safety at work. In addition, Sedarmayanti (2011: 23) adds that the factors that can influence the formation of a work environment are the relationship among workers and the relations among worker and managers.

\section{Research Methods}

\subsection{Data Collection Techniques}

To obtain data regarding the assessment of Individual Characteristics, Organizational Characteristics, Work Environment, Employee Performance and Organizational Work, it was collected by using questionnaires. The questionnaire method is a series or listed question which is structured systematically then it is sent to and filled by the respondents. After the questionnaire was filled in, it was sent back (bungin, 2006: 122). The questionnaire that is used is the optional type for facilitating the respondent in reading the answers because the alternative answer is provided and it needs less time to answer it. The questionnaire contains questions that are related to the research variables.

\subsection{Data Analysis Methods}

The equipment for data analyzing which is used in the study is the structural modelling (SEM) with the help of Amos program. The SEM equation is a group of statistical techniques that allow the testing of a series of relatively complicated relationships e (Ferdinand, 2012: 181). SEM is able to incorporate latent variable into the analysis.

Latent variables are the unobserved concept that is approximated by observed or measured variables which are obtained by the respondent through data collection methods (survey, test, observation) and are often called manifestation variables (Ghozali, 2014). The advantage of SEM application in management research is because it has the ability to confirm the dimensions of a concept or the factors which is very common in management and its ability in measuring. 


\subsection{Research Results}

\subsubsection{SEM Analysis}

The results of data processing for a full analysis of SEM models are shown in Figure 4.1.

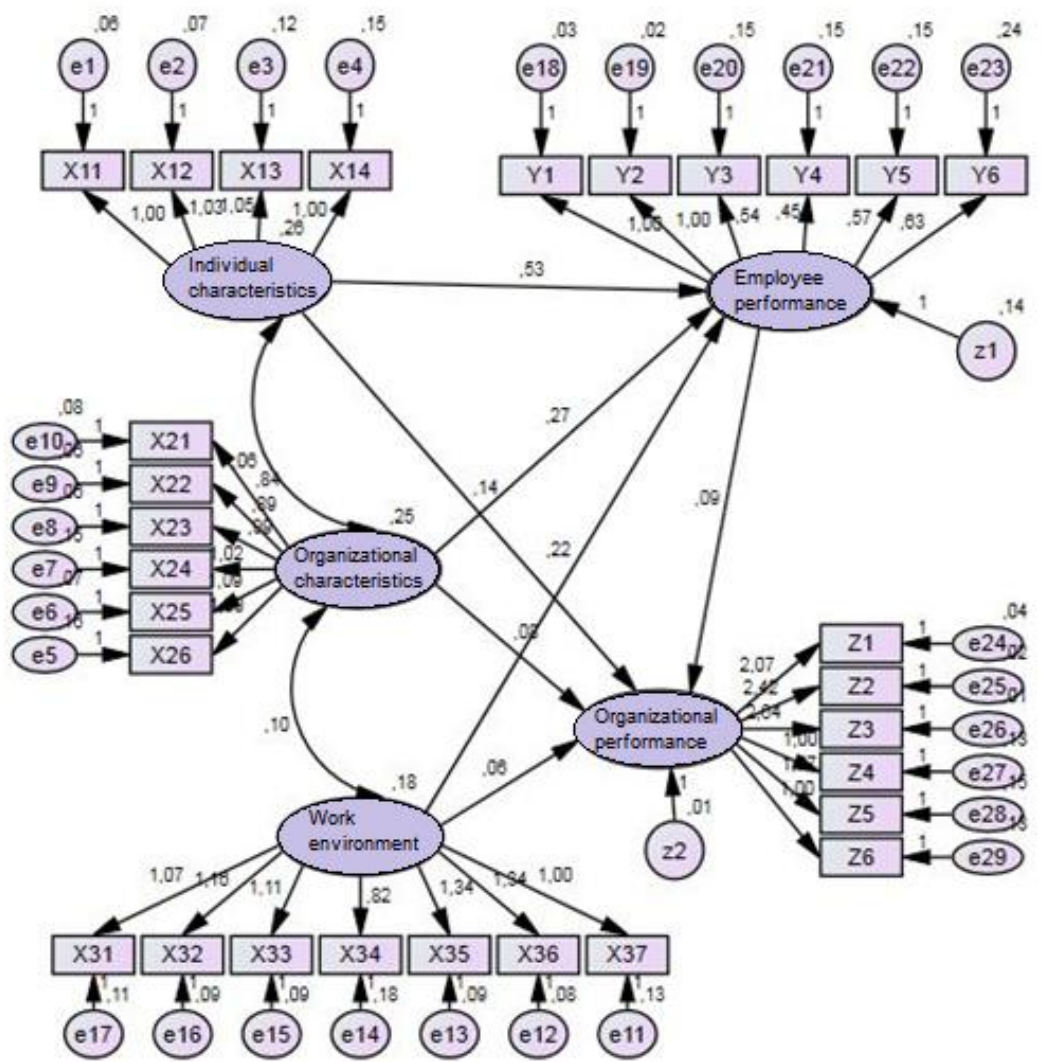

Based on the Figure, it can be explained the influence of each variable, namely individual characteristics, organizational characteristics, work environment on employee performance and also the indirect influence of employee organizational performance through employee performance.

\subsubsection{Hypothesis Testing}

The results of SEM processing as in Table 4.1 are as follows.

Tabel 4.1 Hasil Pengujian Hipotesis

\begin{tabular}{|lll|lccc|}
\hline & & & Estimate & S.E. & C.R. & P \\
\hline Employee performance & $<---$ & Individual characteristics & 0,531 & 0,083 & 6,369 & 0,000 \\
Employee performance & $<---$ & Organizational characteristics & 0,265 & 0,093 & 2,841 & 0,004 \\
Employee performance & $<---$ & Work environment & 0,222 & 0,105 & 2,122 & 0,034 \\
Organizational performance & $<---$ & Individual characteristics & 0,140 & 0,041 & 3,381 & 0,000 \\
Organizational performance & $<---$ & Organizational characteristics & 0,079 & 0,033 & 2,393 & 0,017 \\
Organizational performance & $<---$ & Work environment & 0,062 & 0,034 & 2,801 & 0,072 \\
Organizational performance & $<---$ & Employee performance & 0,089 & 0,037 & 2,382 & 0,015 \\
\hline
\end{tabular}

Based on the results of SEM analysis in Table 4.1 and statistical equations (1) and (2), the following results can be formulated as follow:

Employee performance $=0.531$ Individual characteristics +0.265 Organizational characteristics +0.222 Work environment

Organizational performance $=0.140$ Individual characteristics +0.079 Organizational characteristics + 0.062 Work environment + 0.089 Employee performance 
The influence of individual characteristics on employee performance obtains a CR value of 6.369 with a significance level at $5 \%$ of 0.000 . Thus it can be concluded that individual characteristics have an influence in improving employee performance. The influence of individual characteristics on employee performance is 0.531 or $53.1 \%$. This indicates that the better characteristics of individuals will provide a positive and real influence in improving employee performance.

The influence of organizational characteristics on employee performance obtains a CR value of 2.841 with a significance level at $5 \%$ of 0.004 . Thus it can be concluded that organizational characteristics have an influence in improving employee performance. The influence of organizational characteristics on employee performance is 0.265 or 26.5\%. This indicates that the higher the level of organizational characteristics will further improve employee performance.

The influence of the work environment on employee performance obtains a CR value of 2.122 with a significance level at $5 \%$ of 0.034 . Thus it can be concluded that the work environment has an influence in improving employee performance. The influence of the work environment on employee performance is 0.222 or $22.2 \%$. This indicates that the higher the level of the work environment will further improve employee performance.

The influence of individual characteristics on organizational performance obtains a CR value of 3.381 with a significance level at $5 \%$ of 0.000 . Thus it can be concluded that individual characteristics have an influence on organizational performance. The influence of individual characteristics on organizational performance is 0.140 or $14.0 \%$. This indicates that the higher the individual characteristics will give a direct influence on improving organizational performance.

The influence of organizational characteristics on organizational performance obtains a CR value of 2.393 with a significance level of $5 \%$ of 0.017 . Thus it can be concluded that organizational characteristics have an influence in improving organizational performance. The influence of organizational characteristics on organizational performance is 0.079 or $7.9 \%$. This indicates that the higher the organizational characteristics that are owned will have an influence on improving organizational performance.

The influence of the work environment on organizational performance obtains a CR value of 2.801 with a significance level at $5 \%$ of 0.072 . Thus it can be concluded that the work environment does not have an influence in improving organizational performance.

The influence of employee performance on organizational performance obtains a CR value of 2.382 with a significance level at $5 \%$ of 0.015 . Thus it can be concluded that employee performance has an influence on organizational performance. The influence of employee performance on organizational performance is 0.089 or $8.9 \%$. This indicates that the higher the employee performance will have a direct influence on improving organizational performance.

Furthermore, the test results of each hypothesis above will be presented briefly in Table 4.2 about the hypothesis conclusions as below.

Table 4.2 The Conclusion of Direct Influence Hypothesis

\begin{tabular}{|l|l|l|l|l|}
\hline No & Hypothesis & $\begin{array}{l}\text { CRCut } \\
\text { off }>1.96\end{array}$ & $\begin{array}{l}\text { P-Value } \\
\text { Cut off }<0.05\end{array}$ & Information \\
\hline 1 & $\begin{array}{l}\text { Testing the influence of independent variables on } \\
\text { individual characteristics (X1) with intervening } \\
\text { variables on employee performance (Y) }\end{array}$ & 6.369 & $\begin{array}{l}0.000 \\
(\mathrm{Sig},<5 \%)\end{array}$ & $\mathrm{H}_{1}$ Accepted \\
\hline 2 & $\begin{array}{l}\text { Testing the influence of independent variable on } \\
\text { organizational characteristics (X2) with } \\
\text { intervening variables on employee performance } \\
\text { (Y) }\end{array}$ & $\begin{array}{l}0.004 \\
(\text { Sig, }<5 \%)\end{array}$ & $\mathrm{H}_{2}$ Accepted \\
\hline 3. & $\begin{array}{l}\text { Testing the influence of independent variables on } \\
\text { work environment (X3) with intervening variables } \\
\text { on employee performance (Y) }\end{array}$ & 2.122 & $\begin{array}{l}0.034 \\
(\text { Sig, }<5 \%)\end{array}$ & $\mathrm{H}_{3}$ Accepted \\
\hline 4 & $\begin{array}{l}\text { Testing the influence of independent variables on } \\
\text { individual characteristics (X1) with organizational } \\
\text { performance variables (Z) }\end{array}$ & 3.381 & $\begin{array}{l}0.000 \\
(\text { Sig, }<5 \%)\end{array}$ & $\mathrm{H}_{5}$ Accepted \\
\hline 5 & $\begin{array}{l}\text { Testing the influence of independent variable on } \\
\text { organizational characteristics (X2) with } \\
\text { organizational performance variables (Z) }\end{array}$ & 2.393 & $\begin{array}{l}0.017 \\
(\text { Sig, }<5 \%)\end{array}$ & $\mathrm{H}_{6}$ Accepted \\
\hline 6 & Testing the influence of independent variables on & 2.801 & 0.072 & $\mathrm{H}_{7}$ Rejected \\
\hline
\end{tabular}




\begin{tabular}{|l|l|l|l|l|}
\hline & $\begin{array}{l}\text { work environment (X3) with organizational } \\
\text { performance variables (Z) }\end{array}$ & & $($ Sig, <5\%) & $\mathrm{H}_{4}$ Accepted \\
\hline 7 & $\begin{array}{l}\text { Testing the influence of intervening variables on } \\
\text { employee performance (Y) with organizational } \\
\text { performance variables (Z) }\end{array}$ & 2.382 & $\begin{array}{l}0.015 \\
(\mathrm{Sig},<5 \%)\end{array}$ \\
\hline
\end{tabular}

***, Significant at Level $1 \%$

In table 4.2 it can be explained that individual characteristics, organizational characteristics, and work environment variables influence employee performance variables. Variables of individual characteristics, organizational characteristics, and employee performance have an influence on organizational performance variables, while work environment variable does not influence organizational performance.

\subsubsection{Mediation Testing}

Testing the mediating effect of individual characteristics on personnel performance variables can be explained as follows:

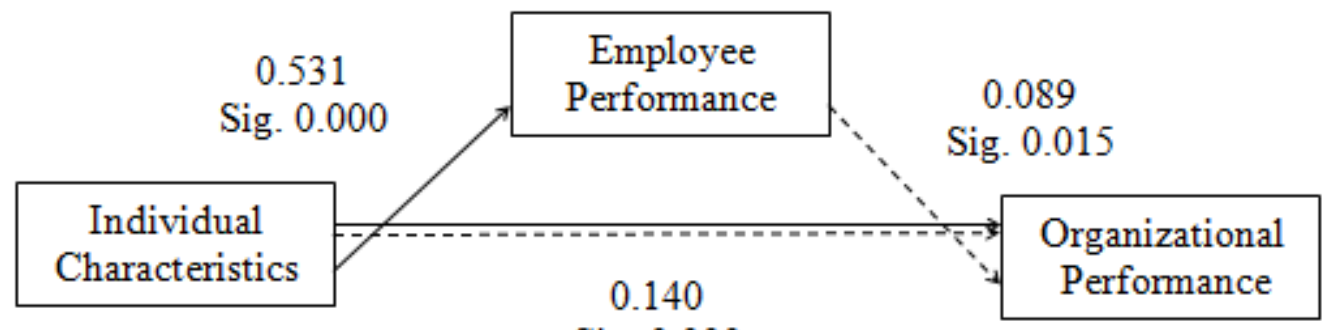

Sig. 0.000

Figure: 4.2. Testing the Mediating Effects of Individual Characteristics on Organizational Performance through Employee Performance

Based on Figure 4.2, it is found that the path coefficient between individual characteristics and employee performance obtains a path coefficient value of 0.531 , while the path coefficient of employee performance on organizational performance is 0.089 . The path coefficient between individual characteristics and organizational performance obtains a value of 0.140 . Because the direct influence between individual characteristics and organizational performance is significant at 5\% the influence of individual characteristics on employee performance is significant at 5\% and the influence of employee performance on organizational performance is also significant at $5 \%$, it can be concluded that employee performance variables act as variables that mediate the relationship between individual characteristics of organizational performance. The role of mediation which is played by employee performance is partially mediating. The results show that testing the mediating effect of organizational characteristic on employee performance variables can be explained as follows:

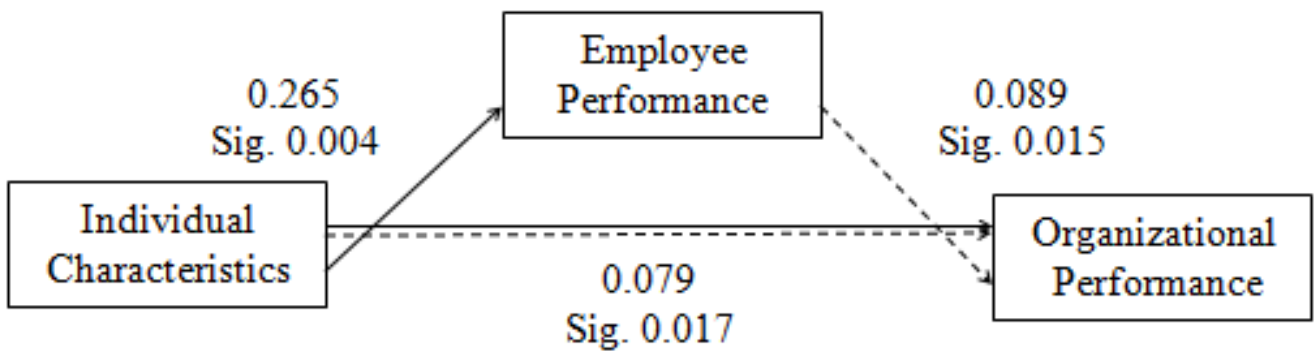

Figure: 4.3. Testing the Mediating Effects of Organizational Characteristics on Organizational Performance through Employee Performance

Based on Figure 4.3, it is found that the path coefficient between organizational characteristics and employee performance obtains a path coefficient value of 0.265 , while the path coefficient of employee performance for organizational performance is 0.089 . The path coefficient between organizational characteristics and organizational performance obtains a value of 0.079. Because the direct influence between organizational characteristics and organizational performance is significant at 5\%, the influence of organizational characteristics on employee performance is significant at 5\%, and the influence of employee performance on organizational performance is also significant at $5 \%$, it can be concluded that employee performance variables act as variables that mediate the relationships between organizational characteristics on organizational performance. 
The role of mediation which is played by employee performance is partially mediating. The results show that testing the mediating effect of the work environment on employee performance variables can be explained as follows:

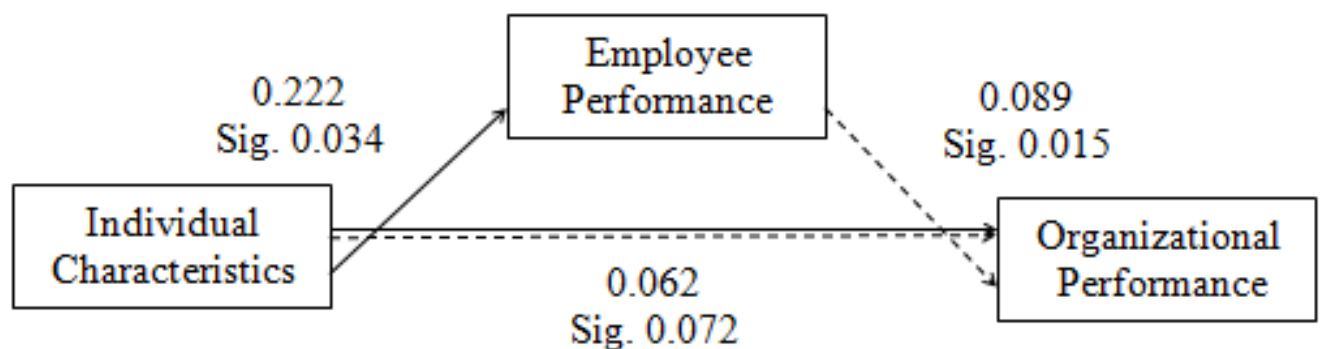

\section{Figure: 4.4. Testing the Mediating Effect of Work Environment on Organizational Performance through Employee Performance}

Based on Figure 4.4, it is found that the path coefficient between the work environment and employee performance obtains a path coefficient value of 0.222 , while the path coefficient of employee performance on organizational performance is 0.089 . The path coefficient between organizational characteristics and organizational performance obtains a value of 0.062. Because the direct influence between work environment and organizational performance is not significant at 5\%, and the influence of employee performance on organizational performance is also significant at 5\%, it can be concluded that employee performance variable acts as a variable that mediates the relationship between work environment and organizational performance. The role of mediation which is played by employee performance is fully mediating.

\subsection{Conclusions}

\subsubsection{Descriptive Conclusions}

Referring to the study results, the conclusions of this study are as follows.

1. Individual characteristic variables in this study obtain an overall average value of 4.35 , or the responses of respondents to the questions of individual characteristics are to agree.

2. Organizational characteristic variables obtain an overall average value of 4.33, or the responses of respondents to the questions of organizational characteristic are to agree.

3. Work environment variables in this study obtain an overall average value of 4.18 , or the responses of respondents to the questions of the work environment are to agree.

4. Employee performance variables produce an overall average value of 4.18 , or the responses of respondents to the questions of employee performance are to agree.

\subsubsection{Verification Conclusions}

Based on the previous description, the conclusions of this study are as follows.

1. Individual characteristics variables have a significant influence on employee performance variables.

2. Organizational characteristics variable have a significant influence on employee performance variables.

3. Work environment variables have a significant influence on employee performance variables.

4. Employee performance variable has a significant influence on organizational performance variables.

5. Individual characteristics variables have a significant influence on organizational performance variables.

6. Organizational characteristics variable have a significant influence on organizational performance variables.

7. Work environment variables do not have a significant influence on organizational performance variables.

8. Employee performance variables mediate the influence of individual characteristics of organizational performance.

9. Employee performance variables mediate the influence of organizational characteristics on organizational performance.

10.Employee performance variables mediate the influence of the work environment on organizational performance.

\subsection{Suggestions}

The author provides several suggestions for further research, including:

1. In order to increase the scope of the study area and add other variables that are expected to influence employee performance and organizational performance, other variables such as leadership and career paths; 
2. Practical advice that can be given to the relevant Office, namely, the study results can be used as material for consideration in meeting the needs of employees in terms of individual characteristics, so that later the employee performance to work is better.

\section{Daftar Pustaka}

Amin, Muhammad. (2014), Pengaruh Pendidikan dan Lingkungan Kerja Terhadap Kinerja Pegawai Dinas Pendapatan Kota Medan. Jurnal Ekonomi Managemen. Vol.3. No.4 : 54 - 62.

Amstrong, Mischael, (1999), "Manajemen Sumber Daya Manusia. Terjemahan Sofyan dan Haryanto". PT. Elex Media Komputindo. Jakarta.

Arikunto, Suharsimi. (2013), "Prosedur Penelitian Suatu Pendekatan Praktik", PT. Rineka Cipta. Jakarta.

Ardana, Comang \& Mujianti Utama. (2012), "Manajemen Sumber Daya Manusia”, Penerbit : Graha Ilmu, Jakarta.

Ardana, K., Mujiati, N. W., \& Sriathi, A. A. (2009). "Perilaku Keorganisasian”. Edisi 2. Yogyakarta: Graha Ilmu.

Abdi, Akbar. (2009), Pengaruh Karakteristik Pekerjaan, Karakteristik Organisasi, Karakteristik Individu, Terhadap Kepuasan Kerja Karyawan, pada Bank Swasta di Provinsi Sulawesi Selatan. Jurnal, Analisis September 2009. Vol.6. No. 2 ; 183-192.

Arief, Subyantoro. (2009), Karakteristik Individu, Karakteristik Pekerjaan, Karakteristik Organisasi, dan Kepuasan Kerja Pengurus yang dimediasi oleh Motivasi kerja. Jurnal Managemen dan Kewirausahaan. Vol.11 No.1, Maret, 2009; 11-19.

Byrne, M. B. (2012), Structural Equation Modelling With Amos; Basic concepts, Application and Programming. Lawrance Arlbaum Associates, New Jersey.

Bungin, B. (2006: 122), “Analisis Data Penelitian Kualitatif. Jakarta: Raja Grafindo.

Desi Saputra Rafiie, (2017), "Pengaruh Kompetensi, Gaya Kepemimpinan, Budaya Kerja dan Lingkungan Kerja Terhadap Kepuasan Kerja Pegawai dan Dampaknya terhadap Kinerja Pegawai”, Study pada kantor Kementrian Agama Kabupaten Aceh Barat.

Daft, L. Richard. (2012), Managemen, Jakarta : Salemba, Empat : Hasibuan (2012), Organisasi dan Motivasi, Jakarta, Bumi Aksara.

Dessler, Gary. (2011), Managemen Sumber Daya Manusia. Alih Bahasa Benyamin Molan Edisi Bahasa Indonesia, Jilid kedua, Prenhallindo, Jakarta.

Endang Suswanti. (2012), "Karakteristik Individu dan Karakteristik Organisasi Pengaruhnya terhadap Motivasi dan Kinerja Bidan Pada Rumah Sakit Umum Pemerintah Daerah Tapal Kuda Jawa Timur. Jurnal Pekan Ilmiah Dosen FEB UKSW, 14 Desember 2012.

Faradila Hasibuan, et. al (2018), "Pengaruh lingkungan kerja dan budaya organisasi terhadap motivasi dan dampaknya terhadap kienerja” karyawan PT. Garuda Indonesia (TBK) Cabang Medan. Jurnal Manajemen Sains. Vol. 06 No.3, Juli 2018.

Fahreza, et. al (2017), Pengaruh Motivasi Kerja, Lingkugan Kerja, dan Budaya Organisasi Terhadap Kinetja Karyawan dan Dampaknya pada Kinerja Bank Aceh Syariah Banda Aceh, Jurnal Magister Manajemen, FEBU. ISSN. 2302-0199. Pp 115-122.

Fisella. W K, et. al. (Juni 2014), "Hubungan Karakteristik Individu dengan Kinerja Perawat", Studi pada ruang rawat inap penyakit dalam RSUD Datoe Binangkang Kabupaten Bolang Mongondow.

Flippo, Edwin. B. (2013), "Managemen Personalia". Edisi Revisi. PT. Gelora Aksara Pratama; Jakarta

Fretilino, Rufino DE A.P. (2012), "Pengaruh Kepemimpinan, Motivasi dan Lingkungan Kerja Terhadap Kinerja Karyawan", Studi pada Grand Manhattan Club.

Ferdinand, Augusty. (2012), Metode Penelitian Manajemen, Semarang, Badan Penerbit Universitas Diponegoro.

Ferdinand. (2006), Metode Penelitian Manajemen, BP. Undip, Semarang.

Ferdinand, (2005), Structural Equation Modelling, Edisi 3, Semarang, CV. Indoprint.

Ferdinand, (2002), Structural Equation Modelling, Dalam penelitian Managemen, BP, Undip, Semarang.

Ghozali Imam, (2014). Aplikasi Analysis Multivariat dengan Program IBM SPSS 21. Edisi 7. Penerbit Universitas Diponegoro, Semarang.

Hair, J.F. Anderson, et. al. (2013), Multivariate Data Analysis, 7/E. / Prentice Hall. Person Educatinal International.

Harun. (2012), Faktor-faktor yang mempengaruhi Kinerja Karyawan dan Dampaknya Terhadap Kinerja Organisasi. Jurnal Ekonomi Pembangunan. Vol.3 No.1.

Ikhsan, Agusniwar, et. al. (2017), Pengaruh Kompleksias Tugas dan Locus of Control Terhadap Kinerja Karyawan, pada PT. Bank Rakyat Indonesia Cabang Meulaboh. Jurnal Magister Managemen. Fakultas Ekonomi dan Bisnis. Vol. 1 No. 1, September 2017 - 16. 
Imam Gunanjar, 2015. "Pengaruh Kompetensi, Penempatan, dan Kompensasi terhadap Kepuasan Kerja Pegawai serta Dampaknya pada Kinerja Pegawai”, Study pada Kantor Perwakilan BKKBN Provinsi Aceh.

Kanestren, D. R. (2009). "Analisis hubungan karakteristik individu dan lingkungan kerja dengan kinerja perawat di unit rawat inap RS Pertamina Jaya". Tesis Fakultas Kesehatan Masyarakat Universitas Indonesia Jakarta http://www.lontar.ui.ac.id

Lela. Harmiyati, et. al. (2016), Pengaruh Karakteristik dan Kapabilitas Individu, Serta Karakteristik Organisasi Terhadap Persepsi Kinerja Perawat Perkesmas. Study pada Puskesmas Kota Palembang. Jurnal Kedokteran dan Kesehatan, Volume 3, No.1, Januari 2016; 341-349.

Liana Dewi Taufiq. (2015), "Pengaruh Karakteristik Individu, Karakteristik Organisasi, dan Lingkungan Kerja Terhadap Kinerja Pegawai, Study pada Perwakilan BKKBN Provinsi Sulawesi Tengah".

Lidyana, (2007). "Pengaruh Kepribadian dan Motivasi terhadap Organizational Citizenship Behavior (OCB)", pada Rumah Sakit Adi Husada Surabaya, Surabaya: FE UKWMS, Perpustakaan.

Mahsud, Muhammad. (2012), "Pengembangan Kinerja Sektor Publik", Yogyakarta, BPFE.

Mahsun, (2006), "Pengembangan Kinerja Sektor Publik", Yogyakarta, BPFE.

Mangkunegara, A P \& Tinton R O, (2015). Effect of Work Discipline, Work Motivation and Job Satisfaction on Employee Organizational Commitment in the Company (Case Study in PT. Dada Indonesia. Universal of Management. Vol. 3 No.8. 318-328.

Mangkunegara, A P. (2012). "Manajemen Sumber Daya Manusia”. Liberty. Yogyakarta.

Mangkunegara, A P. (2010), "Managamen Sumber Daya Manusia”, PT. Remaja Rosdakarya, Jakarta.

Mangkunegara, A P. (2009), "Manajemen Sumber Daya Manusia”. Bandung. Penerbit Remaja Rosdakarya.

Mangkunegara, A.P. (2002), Manajemen Sumber Daya Manusia, PT. Remaja Rosdakarya, Bandung.

Mariadi, (2015), "Pengaruh Kompensasi, Motivasi Kerja dan Lingkungan Kerja Terhadap Kinerja Karyawan serta Implikasinya pada Kinerja" Study Pada Kantor Pusat Operasional PT. Bank Aceh.

Mas'ud Fuad. (2014), Pemimpin dan Kepemimpinan, CV. Rajawali, Jakarta.

Malhotra, K Naresh. (2011), Marketing Research: An applied orientation (5th Edition), Upper Saddle River. NJ: Prentice Hall.

Mathis, R. L. \& Jackson. H. J (2011). Human Resource Management. South Western Cengage Learning.

Nadira. Astri. (2015), Pengaruh Karakteristik Individu dan Lingkungan Kerja terhadap Kinerja Karyawan devisi SDM pada PT. Perkebunan Nusantara III Medan

Nela. P R, et. al, (2014), Pengaruh Lingkungan Kerja Terhadap Kinerja Karyawan. Jurnal Administrasi Bisnis, Vol.8, No.2, Maret 2014.

Nike Norma Epriliyana. (2012), "Pengaruh Karakteristik Individu dan Lingkungan Kerja Terhadap Kepuasan Kerja dan Kinerja Operator Bahan Bakar", Pada SPBU Pasti PAS di Kab. Jember.

Nitisemito, Alex S. (2011), Manajemen Personalia, Ghalia Indonesia, Jakarta.

Nitisemito, Alex S. (2009). "Manajemen Personalia". Jakarta. Penerbit Ghalia Indonesia.

Notoadmodjo, Soekidjo. (2009). "Pengembangan Sumber Daya Manusia". Jakarta : Rineka Cipta

Nimran, Umar. (2009), "Perilaku Organisasi”, Cetakan Pertama, Sidoarjo. Laras.

Oktaviana Andriamarta. (2011), "Pengaruh Karakteristik Individu dan Karakteristik Organisasi Terhadap Kinerja Bidan", di Kabupaten Indragiri Hilir.

Panggabean, S.M. (2004), "Manajemen Sumber Daya Manusia". Bogor: Ghalia Indonesia.

Program Pasca Sarja, Fakultas Ekonomi, Universitas Brawijaya, Malang. (2016), "Pengaruh Karakteristik Individu, Remunerasi, dan Karakteristik Pekerjaan Terhadap Kinerja Pegawai Melalui Motivasi kerja", Study pada Pegawai Arsip Nasional Republik Indonesia di Jakarta.

Peraturan Pemerintah Nomor 46. (2011), Tentang "Penilaian Prestasi Kerja Pegawai Negeri Sipil".

Peraturan Kepala BKKBN Nomor 82. (2011), tentang "Organisasi dan Tata Kerja Perwakilan BKKBN Provinsi".

Rivai, Vethzal. (2014), "Managemen Sumber Daya Manusia untuk Perusahaan dari Teori ke Praktek", Cetakan Pertama. PT. Raja Grafindo Persada. Jakarta.

Robbins, S.P. (2012), Perilaku Organisasi. Edisi Bahasa Indonesia. Jilid 1 dan 2, Prinhalindo, Jakarta.

Robbin, S.P dan Judge, T.A. (2008), "Perilaku Organisasi”. Jakarta. Penerbit Salemba Empat.

Robbin, S.P. (2006), Perilaku Organisasi. PT. Indeks Kelompok, Gramedia, Jakarta.

Survey Demografi Kesehatan Indonesia (SDKI). (2017). BPS dan BKKBN.

Survey Demografi Kesehatan Indonesia (SDKI). (2012). BPS, Kementrian Kesehatan \& BKKBN.

Survey Demografi Kesehatan Indonesia (SDKI). (2007). BPS, Kementrian Kesehatan \& BKKBN.

Siregar, M. D. (2014). "Pengaruh Lingkungan Kerja Dan Karakteristik Individu Terhadap Kepuasan Dan

Kinerja Karyawan", Studi Pada PT. Perkebunan Nusantara III Medan.

Sugiyono. (2013), "Metode Penelitian Manajemen", Cetakan Kesatu. Bandung. Alfabeta. 
Sugiyono. (2012), "Metode Penelitian Kuantitatif, Kualitatif dan R \& D". Bandung. Penerbit Alfabeta.

Sugiyono. (2011), "Metode Penelitian Bisnis dan R \& D". Bandung. Alfabeta.

Sugiyono. (2009). "Metode penelitian kuantitatif, kualitatif dan R\&D”. Cetakan Ke-delapan. Bandung. Penerbit Alfabeta.

Sunyoto, Danang. (2013), "Sumber Daya Manusia", Yogyakarta: Certer for Academic Publishing Service.

Sumamur, (2012). Higiene Perusahaan dan Kesehatan Kerja, Jakarta: Gunung Agung.

Sitinjak dan Sugiharto. (2012), "Metodelogi Penelitian Bisnis BPFE", Yogyakarta.

Sinambela, L. P, dkk. (2012), "Reformasi Pelayanan Publik", Jakarta. Penerbit. PT. Bumi Aksara.

Sugiharto. (2012), "Metode Statistika untuk Bisnis dan Ekonomi”, Penerbit, PT. Gramedia Pustaka Utama.

Sugijanto, H. (2011), "Pengaruh antara Karakteristik Individu dan Karakteristik Kerja terhadap Motivasi dan Kepuasan Kerja" pada SMA di Surabaya.

Simanjuntak. Payaman. J. (2011), "Manajemen dan Evaluasi Kinerja”. Penerbit. Fakultas Ekonomi Universitas Indonesia.

Simanjuntak. (2010), Manajemen Sumber Daya Manusia, Cetakan Kedua. Yogyakarta: STIE YKPN.

Sudarsono, Hari. (2010), "Pengaruh Karakteristik Pekerjaan dan Karakteristik Organisasi Terhadap Kepuasan Kerja Karyawan pada Puskesmas Sumber Manjing Wetan di Malang. Jurnal Aplikasi Manajemen, Vol.8 No. 3 Agustus 2010.

Sedarmayanti. (2013), "Manjemen Sumber Daya Manusia, Reformasi Birokrasi dan Manjemen Pegawai Negeri”, Cetakan ke enam. PT. Refika Aditama. Bandung.

Sedarmayanti. 2011. "Manajemen Sumber Daya Manusia, Reformasi Birokrasi dan Manajemen Pegawai Negeri Sipil”, Cetakan kelima. PT Refika. Bandung.

Sedarmayanti. 2007. "Manajemen Sumber Daya Manusia: Reformasi Birokrasi dan Manajemen Pegawai Negeri Sipil". Cetakan Pertama. Bandung: Penerbit PT.Refika Aditama.

Sedarmayanti. 2001. "Sumber Daya Manusia Dan Produktivitas Kerja”. Bandung. Penerbit Mandar Maju.

Simamora. H. (2011), Manajemen Sumber Daya Manusia", Yogyakarta, STIE. YKPN.

Simamora. (2009), "Manajemen Sumber Daya Manusia dan Lingkungan Kerja”, Pionir Jaya Bandung.

Simamora, Henry. (2006). "Manajemen Sumber Daya Manusia", edisi ketiga, Cetakan kedua, Yogyakarta: Penerbitan STIE YKPN.

Simamora. H. (2004), "Manajemen Sumber Daya Manusia", Edisi Ketiga Yogyakarta. Sekolah Tinggi Ilmu Ekonomi YKPN.

Suyanto, (2013), "Menjadi Guru Profesional strategi meningkatkan kualifikasi dan kualitas guru di Era Global”, Jakarta : Erlangga.

Sugito, P dan Smartono. (2005). "Manajemen Operasional”. Malang: Banyumedia.

Sujak. A. (1990), "Kepemimpinan Manajer", Eksistensi dalam Prilaku Organisasi, Cetakan Pertama. Jakarta. Rajawali.

Tita Budi Astuti. (2017), Analisis Lingkungan Kerja, Karakteristik Individu dan Motivasi Pengaruhnya terhadap Kinerja Karyawan, Study pada PT. Swasta STIE Malangkucecwara, Malang, JABM, Vol.24 No.2 Tahun 2017.

Toha Miftah. (2014), “Kepemimpinan Dalam Manajemen”, Jakarta. PT. Raja Grafindo Perkasa.

Toha Miftah. (2012), “Kepemimpinan Dalam Manajemen”, Jakarta. PT. Raja Grafindo Perkasa.

Ting, Y. (1997). The determinant of Job Satisfaction of Federal Government Employees, Journal of Public Personnel Management, Volume 26, No.3, 313-334.

Undang-undang Nomor 5. (2014), tentang “Aparatus Sipil Negara”.

Undang-undang Nomor 52. (2009), tentang Kependudukan dan Pembangunan Keluarga.

Wiwin Candra, et. al. (2018), "Pengaruh Lingkungan Kerja dan Kepemimpinan Terhadap Semangat Kerja dan Kinerja Pegawai", Studi di Lingkungan Dinas Pendidikan dan Kebudayaan Kabupaten Indragiri Hulu.

Wibowo. (2016), "Managemen Kinerja". Edisi Kelima. Rajawali Pers. Jakarta.

Wibowo. (2013), "Manajemen Kinerja”, Jilid II. Jakarta. PT. Raja Grafindo Persada.

Waldman David, A. (2012), "The Contribution of Total Quality Management to A Theory of Work Performance", Academy of Management Review, Vol. 19.

Wahab, Abdul Azis. (2008). "Anatomi Organisasi dan Kepemimpinan Pendidikan”. Bandung. Alfabeta.

Wijayanto. (2007), Dasar-dasar Ilmu Organisasi, Yogyakarta. Andi, Yogyakarta

Winarno. (2005), "Pengaruh Karakteristik Individu, Karakteristik Pekerjaan dan Karakteristik Organisasi terhadap Kepuasan Kerja”, Studi terhadap Dosen Universitas Swasta di Kopertis Wilayah Daerah Istimewa Yogyakarta. Jurnal Buletin Ekonomi, Vol.3, No.3, Desember 2005. 
Yufrizal. (2015), "Peranan Kepemimpinan, Pendidikan dan Pelatihan (Dilat) dan Insentif dalam Meningkatkan Produktifitas Kerja Pegawai Serta Dampaknya pada Kinerja", Study pada Sekretariat Dewan Perkawilan Aceh.

Viktor O. Lawalata, Erika, Vol. 06. No.01, (2012), "Pengaruh Karakteristik Organisasi Terhadap Keberhasilan Implementasi Sistem ERP".

Zainul Hidayat \& Muchamad Taufiq, (2012), Pengaruh Lingkungan Kerja dan Disiplin Kerja serta Motivasi Kerja Terhadap Kinerja Karyawan, Study pada PDAM Lumajang, Jurnal WIGA, Vol.2, No.1, Maret 2012. 